\title{
Citizen participation and citizen satisfaction in the New Rural Development in Nha Be District between 2016-2020
}

\author{
Ha Minh Tri ${ }^{1 *}$, Phan Thi Bich Thuy ${ }^{1}$ \\ ${ }^{1}$ International University - Vietnam National University - HCMC, Vietnam \\ "Corresponding author: hmtri@hcmiu.edu.vn
}

\begin{abstract}
ARTICLE INFO
ABSTRACT

DOI: $10.46223 / \mathrm{HCMCOUJS.}$

soci.en.11.2.1911.2021

Received: June $03^{\text {rd }}$, 2021

Revised: June $18^{\text {th }}, 2021$

Accepted: June $21^{\text {st }}, 2021$

Keywords:

citizen participation; citizen

satisfaction; new rural

development; program

effectiveness

The ultimate goal of building a New Rural Development (NRD) (similar to the Saemaul Undong Movement in Korea) is to sustainably improve the material and spiritual life of the people. Our study investigates how citizen participation may influence the effectiveness of the NRD program and citizen satisfaction in implementing the NRD in Nha Be District from 2016 to 2020. Our work adopts a questionnaire-based study designed to collect data from 780 participants using the random cluster sampling technique. Our findings reveal that citizen participation significantly affects citizen satisfaction via the mediating role of the NRD program effectiveness but not directly between citizen participation and citizen satisfaction. Finally, our study offers theoretical contributions and policy implications for decision-makers and NRD program managers.
\end{abstract}

\section{Introduction}

Implementing a New Rural Development (NRD) (similar to Saemaul Undong in Korea) is a major policy and program of the Government to build a new rural economic infrastructuremodern society gradually, economic structure and forms of production organization rationally, linking agriculture with the rapid development of industry and services. This program further associates rural development with urban areas following a planning scheme to establish a democratic and stable rural society, rich in national cultural identity, ecologically environmental protection. Additionally, this program maintains and improves the local security, material and spiritual life of the people (NRD Program, 2016). Furthermore, the involvement of the program's citizens in deciding the program's effectiveness is important. To succeed, citizens must participate actively to the program to produce program effectiveness and satisfaction (Baek, Kim, \& Lee, 2012; Yoo, 1987). The NRD has started in 2010 on a national scale. It has been successfully implemented, recognizing that in addition to the Government's support and the contribution of society, it is necessary to maximize human resources and mobilize to socialize to achieve the goals sustainably.

In Nha Be District, building its NRD with its own particularity requires the consensus of all people, the political system, and households. Businesses, industrial parks, individuals, and organizations inside and outside the district can fully mobilize resources and promote available strengths and advantages to help complete the project ahead of schedule and improve the quality of the entire program.

On the other hand, building the NRD with appropriate planning orientation, investment in infrastructure, environment and social services with orientation to urban transformation in order 
to gradually prepare for urbanization helps avoid wasting investment resources. Furthermore, it is essential that the local citizens or people have the main role in building NRD; the consent of the people is a decisive factor for the program's success. It is necessary to regularly propagate and mobilize individuals and organizations to actively improve the implementation of the NRD to ensure that people are both subjects and beneficiaries of the results (McArdle, 2012; Tewari \& Isemonger, 1998). Therefore, it is necessary to propagate and mobilize to encourage enterprising actions of the people to promote true democracy and always be transparent and open towards collective interests in deciding the choice of content, inspection, monitoring, and evaluation of the program implementation in each locality (Wi, 2019). It is also critical to mobilize the whole community to work together to complete the individual targets and the program's overall goals for each timeline, geographical location, and environment.

However, there are still limitations in reality on the level of citizen participation. Specifically, environment, infrastructure, social order and safety, traffic, education, health care, culture, etc., are, to some extent, not all protected. Therefore, it is important for all the people to collectively participate in NRD program implementation towards achieving the program goals in all stages of the program. To have an accurate picture of what is going on in terms of citizen participation, NRD program effectiveness and satisfaction, it is thus important to evaluate the level of citizen participation that may affect citizen satisfaction of the people in implementing the NRD program in Nha Be District during 2016 - 2020 and this is quite significant for program implementation in the period of 2021 - 2025. Currently, there have not been any studies to examine the relationships between citizen participation, NRD program effectiveness and satisfaction of the NRD program in Nha Be District. Therefore, to fill this gap, it is critical to conduct this research in Nha Be District. Our study investigates how citizen participation may influence the effectiveness of the NRD program and citizen satisfaction in implementing the NRD in Nha Be District in the period of 2016 - 2020.

\section{Literature review and hypotheses development}

\subsection{Citizen participation}

Public management scholars often use terms such as public or citizen participation (Callahan, 2007; King, Feltey, \& Susel, 1998; Langton, 1978; Wang, 2001). Wang (2001, p. 302) characterizes public participation as "citizen involvement in making service delivery and management decision." Callahan (2007, p. 1181) defines citizen participation as "participation in the planning and administrative processes of government."

Citizen participation is seen as necessary to assist in the management or decision-making of the Government (Baiocchi, 2003; Mahjabeen, Shrestha, \& Dee, 2009; Yang \& Callahan, 2007). Citizens participating in government activities will create effective governance, promoting redistribution (Baiocchi, 2003). Public participation is defined as the performance of business operations in managerial and executive decisions (Langton, 1978). Involvement of many people in public service functions, including economic development, public health, education, environmental protection, and public safety (Aryani, Garrett, \& Alsabrook, 2000; Foley, 1998; Iglitzin, 1995; Morgan, 1984).

Inauthentic participation, citizens are the dominant advocates and decision-makers, and the Government is goal setting, providing incentives, monitoring processes, and providing information (Gray \& Chapin, 1998; Plein, Green, \& Williams, 1998). In addition, there are some theories that it is more difficult in urbanized areas than in rural areas in terms of contribution from the people (J. E. Oliver, 2000). However, promoting actual participation is never easy (Handley \& Howell- 
Moroney, 2010). People are more involved in small cities because small communities promote greater social cohesion (Barber, 2004; J. E. Oliver, 2000; Ross \& Levine, 2001). People enjoy interacting with others like themselves because they share common interests and are socialized with the same cultural norms (Costa \& Kahn, 2003). On the other hand, citizens face greater challenges in large cities to build such networks, and there is less cohesion that further impedes their rights than other stakeholders. According to Wang (2001), citizens participate with development agencies in formulating agendas, prioritizing, initiating, and implementing projects by contributing ideas, concerns, materials, money, labor, and time.

Berner (2003) found that many municipalities establish civic participation mechanisms because state laws, attitudes, and state mandates significantly influence their performance when local participation is involved. Callahan (2002) affirms that Citizens Advisory Committees are common and play an important role at the local level. Citizen participation is tied to policy outcomes and improves local service delivery and public programs (Ebdon, 2000, 2002; Roberts, 2004). Public participation has important benefits for governance outside of Government because democratic values are realized by participatory mechanisms (Berner, 2003; Thomas, 1995). According to King et al. (1998), local governments may adopt different strategies to encourage the participation of the people to improve their satisfaction with the services at the local level.

André, Martin, and Lanmafankpotin (2012) contend that the participation of the people in the process by which people participate voluntarily or mandatory and act alone or in groups with the aim to influence the decision to impact the entire community. This participation can take place in two directions inside-outside the institutional framework, and it can be organized by members of social organizations or people who can exercise decision-making. At the same time, it will be influenced by each region's awareness, culture, or geographical conditions, but the level of people's participation in community development activities shows different levels. Arnstein (1969) proposed a "ladder of participation" with eight levels, or rungs, corresponding to increasing degrees of citizens' power in decision making. At the bottom of the ladder are two rungs, Manipulation and Therapy, which Arnstein categorized as Nonparticipation. The middle rungs 03, 04, and 05, identified respectively as Informing, Consultation and Placation, belong to the category of Tokenism. At the top of the ladder, rungs 06, 07, and 08 correspond to Partnership, Delegated Power and Citizen Control, respectively and are classified as Citizen Power. The higher up the ladder an instance of citizen participation can be placed, the more citizens can be sure that their opinions will be integrated into decision making and applied in the interest of their community.

Along the line, citizen participation in government decision-making helps to improve policy in terms of performance, decision legitimacy, citizen response and trust in the Government (E. Berman \& Wang, 2000; King et al., 1998; Walters, Aydelotte, \& Miller, 2000). Inheriting such knowledge with citizen participation is the Government's effort to involve citizens in administrative decisions, making and management processes. Often concentration occurs when managers or administrators interact with citizens, which is different from political participation such as voting in elections, contacting elected officials to vote and campaigning for political candidates (Verba \& Nie, 1987; Verba, Schlozman, Brady, \& Nie, 1993). Following J. E. Oliver (2000), citizen participation can take many forms, ranging from individual volunteering to organizational participation to vote.

\subsection{Citizen satisfaction}

From a theoretical perspective, there can be different perspectives on an individual's life satisfaction. Ramseook-Munhurrun, Lukea-Bhiwajee, and Naidoo (2010) identified factors affecting "customer satisfaction" including procedures, service attitude, staff capacity. Citizen 
satisfaction is very important to public officials because it demonstrates citizens' perceptions of government efforts as well as highlights their preferences, needs of citizens and assessment of local government capacity (Hassett \& Watson, 2003; Kelly, 2003; Miller, 1985).

Tse and Wilton (1988) stated that satisfaction is the user's response before estimating the perceived performance between the previous desire and the actual outcome perceived by that individual user. Therefore, satisfaction is the difference between users' actual perceptions and their expectations (R. L. Oliver, 1999). If the actual perception is not as expected, they will be satisfied; if the actual benefits are higher than the expectations, the phenomenon of satisfaction is high or exceeded (R. L. Oliver, 1999).

Customer satisfaction is an emotional state towards a product or service that has been used (Spreng, MacKenzie, \& Olshavsky, 1996). According to A. K. Smith and Bolton (2002), satisfaction is customers' emotional response to their experience with a certain product or service. R. L. Oliver (1999) stated satisfaction as the overall affective induction to perceive the difference between expectations and feelings after using a product or service. Giese and Cote (2000) consider the customer as the ultimate consumer, and their research identifies three general components of "customer satisfaction" as: (1) Customer satisfaction is an overall emotional response, that is, variations in emotional intensity; (2) That emotional response is associated with the goal of product selection, purchase of goods, or product consumption; and (3) Emotional responses at a particular point in time are generally limited state changes over the duration of the event.

The relationship between citizen participation and satisfaction can also enhance public confidence in the ability of local governments to deliver efficient and effective delivery services (Fleming \& Barnhouse, 2006). Information and government actions are transparent, and citizens have the right to direct oversight of how a city operates and protect their interests through open public forums in the policy process (Bland, 2013). According to Wang (2001), although a policy program attracts people's attention to participate in the policy process, most citizens are not willing to attend public affairs because they are distant from the political issues.

\subsection{NRD program effectiveness}

Cities can improve their public performance and the effectiveness of city service delivery when they incorporate citizen input as part of their performance indicators and citizens can voice their preferences through various mechanisms, such as hearings, local voting or performance measurement systems (G. E. Smith \& Huntsman, 1997; Ho \& Coates, 2004). Citizen participation is valuable to officials, in particular at the local level, since citizen participation often helps public officials establish broad and effective public policy goals. Again, citizens can be active on policy issues, acting as advocates, partners in implementing public programs and evaluators of public services (Epstein, Solomon, \& Grifel, 2000; Ho \& Coates, 2004). Their participation can improve the performance of local services and thereby improve their welfare and livelihoods as well as enhance government capacity (Cuthill \& Fien, 2005; Wang, 2001).

According to Baker, Addams, and Davis (2005), Berner (2003), King et al. (1998), and Wang (2001), citizen participation, public sector satisfaction and efficiency are the main concerns of public officials as they are often related to administrative reform, policy implementation, representativeness, and capacity of the Government. The definition of efficiency is the economic extent to which a process consumes resources, especially time and money, while differential efficiency is the extent to which a process achieves its intended purpose from the point of view of the customer (Roberts, 2004). One way of seeing the problem as being effective is doing it right. Effectiveness is closely related to governance, and Webster-Merriam online defines governance as 
to how a city, company, etc., is controlled by the people who run it. Effectiveness is often measured by the quality of the desired outcome. Effective measurements related to time and cost. In economics, efficiency often focuses on different aspects of the balance between supply and demand.

\subsection{The relationships between participation, effectiveness and satisfaction}

According to $\mathrm{Wu}$ and Jung (2016), making the connection between citizen participation, effectiveness, and citizen satisfaction are also important values that are often overlooked by scholars in the field. They found a significant link between public performance, the involvement of citizens, and overall on satisfaction of citizens with the Government's efforts of the citizens residing in San Francisco. In a similar vein, the relationship between effectiveness and citizen satisfaction with government actions is based on their review and evaluation of service quality, showing that performance affects public service, people's views of their local Government (Wisniewski, 2001). Citizens' views and attitudes towards governments are important in explaining their satisfaction with local services. People are more likely to agree to pay for public services if their perception of public performance by local governments is relatively high, especially in the areas of public safety and emergency services (Donahue, Robbins, \& Simonsen, 2008).

According to Langton (1978), when assessing citizen participation, it is necessary to consider four factors: the purpose of citizen participation; citizen participation activities, subjects of citizen participation, and objects of citizen participation: Purposes citizen participation include discovery, education, measurement, and persuasion in the policy process (Walters et al., 2000). Following Wang (2001), citizen participation can also be specified as setting goals, defining strategies, policies and capacities, monitoring and evaluating government services. Citizen participation activities involve public hearings, citizen advisory councils, workshops, neighborhood meetings, and civic surveys (King et al., 1998; Wang, 2001). Objects of citizen participation are related to representation issues, emphasizing whether the same group of people participate regularly and whether the voice of all social groups, including poor citizens and minorities, are heard (Checkoway, Van Til, \& Langton, 1978; Irvin \& Stansbury, 2004). Subjects of citizen participation refer to government units or functional areas with citizen participation such as economic development, environmental protection, education, public health, policy and public safety (Wang, 2001).

Given the literature on political participation and citizen participation (J. E. Oliver, 2000; Putnam, 1993, 2000; Verba \& Nie, 1987; Verba et al., 1993), few empirical studies have examined participation systematically in the administrative process. They tend to focus on a specific engagement purpose or functional areas such as budgeting (Ebdon, 2000, 2002; Franklin \& Carberry-George, 1999), performance measurement (E. Berman \& Wang, 2000; Poister \& Streib, 1999), or strategic management (Poister \& Streib, 2005; Rivenbark, 2003). Citizen participation activities are considered in a limited number of participation mechanisms (S. Berman, 1997; E. Berman \& Wang, 2000). Therefore, it is appropriate to formulate the following hypotheses:

H1: The purpose of participation positively affects citizen participation in the NRD program

H2: Participatory activities have a positive impact on citizen participation in the NRD program

H3: The topic of participation positively affects citizen participation in the NRD program

H4: Citizen participation positively affects the effectiveness of the NRD program

H5: The effectiveness of the NRD program has a positive impact on citizen satisfaction in the NRD program

H6: Citizen participation positively affects citizen satisfaction in the NRD program 


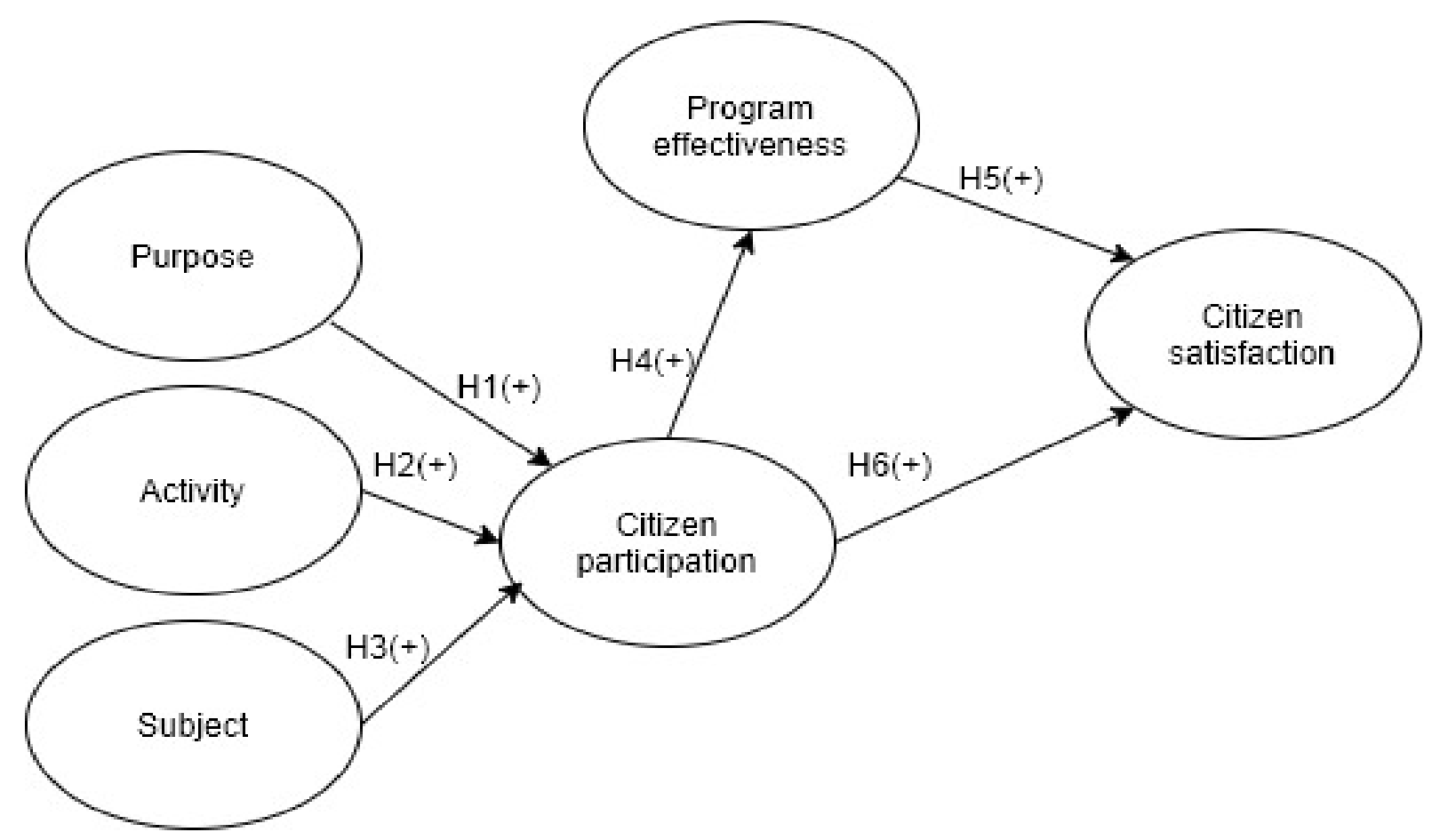

Figure 1. Research model

\section{Methodology}

\subsection{Data collection and sampling}

This study adopts a cross-sectional survey design to validate the proposed hypotheses. The survey targeted respondents participating in the NRD program in Nha Be District during 2016 2020. Our study distributed questionnaires to respondents and collected them back after two weeks. Data collection took place in February of 2021. A pre-test of the questionnaire was conducted with a select group of respondents $(n=17)$ before data collection. The purpose of the pre-test was to determine whether anything was difficult to address because of the sentences, anonymity, formulation or technical terms (Colton \& Covert, 2015). Pretesting also helped to improve construct validity (Shadish, Cook, \& Campbell, 2002). Based on the pre-testing results, modifications were made to the questionnaire to enhance its readability and validity prior to the data collection. Our study used a random cluster sampling technique (Trochim, Donnelly, \& Arora, 2016). Specifically, we selected 35 villages out of 354 in the Nha Be District at random (approximately 10\%). We did not include Nha Be township into the defined population as it is not part of the NRD program. Then we tried to collect data from all the households participating in the NRD program in the selected villages. We sent out 900 questionnaires and received 780 valid responses, yielding an 86.7 percent response rate. This is considered a high response rate and reduces the likelihood of response bias (Cheung, Gillen, Faucett, \& Krause, 2006). All of the respondents were between 18 and 70 when sending the questionnaire. Male respondents make up $50.1 \%$ of the total, while female respondents make up $49.9 \%$.

\subsection{Measures}

Our study uses a five-point Likert scale ranging from " 1 " ("strongly disagree") to "5" ("strongly agree") to measure all items. All six construct measurement scales were taken from the validated literature. Specifically, the scale for citizen participation was taken from Wu and Jung (2016) and Wang (2001); the scales for program effectiveness and citizen satisfaction were taken from Wu and Jung (2016) and Kelly and Swindell (2002). From the original scales, the study 
organized interviews with 17 experts working directly on the NRD program at district and commune levels to operationalize the study constructs before pre-testing them in the field. As a result, the measurement scales comprise a total of 61 items that are ready for data collection.

\subsection{Data analysis}

Data analysis runs an Exploratory Factor Analysis (EFA) using IBM SPSS 24 to validate the study scales. The next step of analysis is to apply a two-step approach recommended by Anderson and Gerbing (1988) to conduct measurement model and structural model analyses using IBM Amos 24. During this procedure, relevant tests are conducted to evaluate how reliable and valid (convergent and discriminant) the measurement model is. Second, it assesses a structural model by running a path analysis to verify the proposed hypotheses.

\subsection{Findings}

Initially, an EFA procedure was conducted using principal component analysis (PCA) with varimax rotation. The purpose is to generate validated factors or constructs that could be used in subsequent analysis (Hair, Black, Babin, \& Anderson, 2019). The process eliminated items with factor loading below 0.50 that were not eligible for further analysis (Hair et al., 2019). This process returned six factors with 28 items ready for Structural Equation Modelling (SEM) analysis.

\subsection{Measurement model evaluation}

Data were analysed using IBM SPSS Statistics version 24.0. Table 1 shows that all indices CMIN/DF, CFI, TLI, SRMR and RMSEA all passed the cut-off criteria (Hu \& Bentler, 1999).

Evaluation of the reliability and validity of the model: The reliability and validity of the measurement model are assessed by the following parameters: Composite Reliability (CR), an Average of Extracted Variance (AVE), Maximum Shared Variance (MSV) and mean shared variance (ASV) following Hair et al. (2019).

\section{Table 1}

Model fit measures

\begin{tabular}{|l|c|c|c|c|}
\hline \multirow{2}{*}{ Index } & \multirow{2}{*}{ Actual values } & \multicolumn{3}{c|}{ Cut-off Criteria } \\
\cline { 3 - 5 } & & Terrible & Acceptable & Excellent \\
\hline CMIN & $1,211.812$ & -- & -- & -- \\
\hline DF & 323.000 & -- & -- & -- \\
\hline CMIN/DF & 3.752 & $>5$ & $>3$ & $>1$ \\
\hline CFI & 0.941 & $<0.90$ & $<0.95$ & $>0.95$ \\
\hline SRMR & 0.056 & $>0.10$ & $>0.08$ & $<0.08$ \\
\hline RMSEA & 0.059 & $>0.08$ & $>0.06$ & $<0.06$ \\
\hline
\end{tabular}

Source: Authors' calculation

Next, the authors evaluate the reliability and validity of the measurement model. Table 2 shows that the Composite Reliability (CR) of the five latent variables ranges from 0.795 to 0.922 and the Average Extracted Variance (AVE) of the five latent variables is from 0.504 to 0.720 . Therefore, it is concluded that the measurement model meets the reliability and validity requirements (Hair et al., 2019). 
Table 2

Results of model reliability and validity

\begin{tabular}{|c|c|c|c|c|c|c|c|c|}
\hline & CR & AVE & MSV & EFF & SUB & ACT & SAT & PUR \\
\hline EFF & 0.922 & 0.629 & 0.525 & $\mathbf{0 . 7 9 3}$ & & & & \\
\hline SUB & 0.901 & 0.565 & 0.552 & $0.574 * * *$ & $\mathbf{0 . 7 5 1}$ & & & \\
\hline ACT & 0.907 & 0.585 & 0.552 & $0.724 * * *$ & $0.743 * * *$ & $\mathbf{0 . 7 6 5}$ & & \\
\hline SAT & 0.795 & 0.504 & 0.145 & $0.381 * * *$ & $0.219 * * *$ & $0.247 * * *$ & $\mathbf{0 . 7 1 0}$ & \\
\hline PUR & 0.885 & 0.720 & 0.530 & $0.664 * * *$ & $0.598 * * *$ & $0.728 * * *$ & $0.328 * * *$ & $\mathbf{0 . 8 4 8}$ \\
\hline
\end{tabular}

Note: $* * *$ significant at $\mathrm{p}<0.001$

Source: Authors' calculation

\subsection{Structural model evaluation}

Results from the model fit analysis in Table 3 show that all model fit indices, including CMIN/DF, CFI, SRMR, RMSEA, achieve model fit criteria from acceptable to excellent levels (Hu \& Bentler, 1999).

Table 3

Structural model fit indices

\begin{tabular}{|l|c|c|c|c|}
\hline \multirow{2}{*}{ Index } & \multirow{2}{*}{ Actual values } & \multicolumn{3}{c|}{ Cut-off Criteria } \\
\cline { 3 - 5 } & & Terrible & Acceptable & Excellent \\
\hline CMIN & $1,486.590$ & -- & -- & -- \\
\hline DF & 376.000 & -- & -- & -- \\
\hline CMIN/DF & 3.954 & $>5$ & $>3$ & $>1$ \\
\hline CFI & 0.932 & $<0.90$ & $<0.95$ & $>0.95$ \\
\hline SRMR & 0.057 & $>0.10$ & $>0.08$ & $<0.08$ \\
\hline RMSEA & 0.062 & $>0.08$ & $>0.06$ & $<0.06$ \\
\hline
\end{tabular}

Source: Authors' calculation

We further conducted a path analysis of the hypothesised relationships in the model. Table 4 presents the path modeling results. It can be seen that except for hypothesis H6, all the hypothesised relationships were significantly confirmed. 


\section{Table 4}

Results of structural model testing

\begin{tabular}{|l|l|c|c|c|}
\hline \multicolumn{2}{|c|}{ Hypothesis } & $\begin{array}{c}\text { Proposed } \\
\text { effect }\end{array}$ & $\begin{array}{c}\text { Path } \\
\text { coefficients }\end{array}$ & Result \\
\hline H1 & $\begin{array}{l}\text { The purpose of participation has a positive } \\
\text { impact on people's participation in new rural } \\
\text { construction }\end{array}$ & + & $0.121^{*}$ & Supported \\
\hline H2 & $\begin{array}{l}\text { Participatory activities have a positive impact } \\
\text { on people's participation in new rural } \\
\text { construction }\end{array}$ & + & $0.656^{* * *}$ & Supported \\
\hline H3 & $\begin{array}{l}\text { The topic of participation positively affects } \\
\text { people's participation in new rural } \\
\text { construction }\end{array}$ & + & $0.315^{* * *}$ & Supported \\
\hline H4 & $\begin{array}{l}\text { Citizen participation positively affects the } \\
\text { effectiveness of the new rural program. }\end{array}$ & + & $0.729^{* * *}$ & Supported \\
\hline H5 & $\begin{array}{l}\text { The NRD program effectiveness has a } \\
\text { positive impact on citizen satisfaction }\end{array}$ & + & $0.319^{* * *}$ & Supported \\
\hline H6 & $\begin{array}{l}\text { Citizen participation positively affects citizen } \\
\text { satisfaction in NRD program }\end{array}$ & + & $0.031^{\mathrm{ns}}$ & Not \\
\hline
\end{tabular}

Note: $*$ significant at $\mathrm{p}<0.05 ; * *$ significant at $\mathrm{p}<0.01$; $* * *$ significant at $\mathrm{p}<0.001$; ${ }^{\mathrm{n} s}$ not significant at $\mathrm{p}<0.05$ Source: Authors' calculation

\section{Discussion}

Our study developed the theoretical model to test the hypothesised relationships between citizen participation, program effectiveness and citizen satisfaction in implementing the NRD program. The empirical findings show that all hypothesised relationships are confirmed except for hypothesis H6. Our findings are similar to other prior research, including Wu and Jung (2016), except for the relationship between citizen participation and citizen satisfaction. Similar to Wisniewski (2001) and Donahue et al. (2008), we also found NRD program effectiveness is significantly related to citizen satisfaction. This relationship is important in explaining how citizen satisfaction is satisfied with the services provided by the NRD program. In addition, King et al. (1998), S. Berman (1997), and Walters et al. (2000) asserted that citizen participation in government decision-making helps to improve policy with regard to effectiveness, decision legitimacy, citizen response and trust in the Government. In a similar vein, Vo (2014) found that level of citizen participation not only contributes to improving investment resources for NRD program but also helps to regain citizen's trust in the implementation of socio-economic development plan, while Tran (2018) and Ban (2016) asserts that citizen participation significantly influences citizen satisfaction because their participation contributes to NRD program.

\subsection{Theoretical contributions}

Our study found citizen participation positively influences citizen satisfaction in implementing the NRD program. This study provides critical empirical evidence and emphasizes the importance of having people participate in effectively implementing the NRD program. The 
better the effectiveness of the NRD program, the better the citizen consensus and better citizen satisfaction. This is especially true in the context of NRD program implementation. Our study provides a theoretical model to study the impact of citizen participation on the NRD program effectiveness and then citizen satisfaction, especially the mediating role of NRD program effectiveness. This fills the knowledge gap and advances our understanding with regard to the relationship between citizen participation and citizen satisfaction, especially in the context of NRD program implementation. Our findings also enrich the growing literature on the role of citizen participation in the public sector in Vietnam.

\subsection{Policy implications}

Decision-makers and NRD program managers should prioritize and promote citizen participation in the implementation of the NRD program. To do that, they should be well prepared and plan carefully to include citizen participation from the beginning of the NRD program or even during the design phase of the NRD program. By doing that, it is expected that the NRD program can efficiently mobilize citizen participation in successfully implementing the NRD program because it can respond appropriately to the citizens' needs and expectations. Ultimately, the NRD program is designed for the people and for the sake of people's civilization, modernization, wealth, and happiness.

\subsection{Limitations and future research directions}

Our work also has several limitations. First, our work only focuses on the NRD program. Future research may concentrate on programs other than NRD, such as socio-economic development plan implementation and compare the results with our study. Second, our study adopts the questionnaire-based survey, collecting only cross-sectional data. Future studies may collect longitudinal data to examine the differences of level of citizen participation in the various stages of the NRD implementation program (e.g., the beginning, the midterm, and the final) to have a more thorough understanding concerning the dynamics between citizen participation, the effectiveness of the NRD program and citizen satisfaction.

\section{ACKNOWLEDGEMENTS}

This research is funded by International University, VNU-HCM, under grant number SV2020-BA-05.

\section{References}

Anderson, J. C., \& Gerbing, D. W. (1988). Structural equation modeling in practice: A review and recommended two-step approach. Psychological Bulletin, 103(3), 411-423. doi:10.1037/0033-2909.103.3.411

André, P., Martin, P., \& Lanmafankpotin, G. (2012). Citizen participation. Retrieved April 22, 2021, from Encyclopedic Dictionary of Public Administration website: https://cerberus.enap.ca/Dictionnaire/63/Index_by_word.enap?by=word\&id=68

Arnstein, S. R. (1969). A ladder of citizen participation. Journal of The American Institute of Planners, 35(4), 216-224. doi:10.1080/01944366908977225

Aryani, G. A., Garrett, T. D., \& Alsabrook, C. L. (2000). The citizen police academy: Success through community partnerships. FBI Law Enforcement Bulletin, 69(5), 16-21. 
Baek, I. R., Kim, P. S., \& Lee, S. C. (2012). Contributions and limitations of Saemaul Undong in Korea for regional development and welfare improvement in less developed countries. Public Administration and Development, 32(4/5), 416-429. doi:10.1002/pad.1639

Baiocchi, G. (2003). Emerging public spheres: Talking politics in participatory governance. American Sociological Review, 68(1), 52-74.

Baker, W. H., Addams, H. L., \& Davis, B. (2005). Critical factors for enhancing municipal public hearings. Public Administration Review, 65(4), 490-499.

Ban, S. C. (2016). Sụ tham gia của người dân vào xây dụng nông thôn mới, xã Việt Lâm, huyện Vị Xuyên, tỉnh Hà Giang [Citizen participation in new rural development program in Viet Lam commune, Vi Xuyen district, Ha Giang Province] (Master's thesis). University of Economics Ho Chi Minh City, Ho Chi Minh City, Vietnam. Retrieved March 15, 2021, from https://digital.lib.ueh.edu.vn/handle/UEH/50866

Barber, B. R. (2009). Strong democracy: Participatory politics for a new age. Berkeley, CA: University of California Press.

Berman, E., \& Wang, X. (2000). Performance measurement in U.S. counties. Public Administration Review, 60(5), 409-420.

Berman, E., \& West, J. R. (2003). What is managerial mediocrity? Definition, prevalence, and negative impact (Part 1). Public Performance \& Management Review, 27(2), 9-29.

Berman, S. (1997). Civil society and political institutionalization. American Behavioral Scientist, 40(5), 562-574. doi:10.1177/0002764297040005003

Berner, M. (2003). Current practices for involving citizens in local government budgeting: Moving beyond method. Public Administration Quarterly, 27(3/4), 410-432.

Bland, R. L. (2013). A budgeting guide for local government. Princeton Junction, NJ: ICMA Press.

Callahan, K. (2002). The utilization and effectiveness of citizen advisory committees in the budget process of local governments. Journal of Public Budgeting, Accounting and Financial Management, 14(2), 295-319.

Callahan, K. (2007). Citizen participation: Models and methods. International Journal of Public Administration, 30(11), 1179-1196. doi:10.1080/01900690701225366

Checkoway, B., Van Til, J., \& Langton, S. (1978). What do we know about citizen participation? A selective review of the literature. In S. Langton (Ed.), Citizen participation in America (pp. 25-42). Lexington, MA: Lexington Books.

Cheung, K., Gillen, M., Faucett, J., \& Krause, N. (2006). The prevalence of and risk factors for back pain among home care nursing personnel in Hong Kong. American Journal of Industrial Medicine, 49(1), 14-22. doi:10.1002/ajim.20243

Colton, D., \& Covert, R. W. (2015). Designing and constructing instruments for social research and evaluation. Hoboken, NJ: Wiley.

Costa, D. L., \& Kahn, M. E. (2003). Civic engagement and community heterogeneity: An economist's perspective. Perspectives on Politics, 1(1), 103-111.

Cuthill, M., \& Fien, J. (2005). Capacity building: Facilitating citizen participation in local governance. Australian Journal of Public Administration, 64(4), 63-80. 
Donahue, A. K., Robbins, M. D., \& Simonsen, B. (2008). Taxes, time, and support for security. Public Budgeting \& Finance, 28(2), 69-86.

Ebdon, C. (2000). The relationship between citizen involvement in the budget process and city structure and culture. Public Productivity \& Management Review, 23(3), 383-393.

Ebdon, C. (2002). Beyond the public hearing: Citizen participation in the local government budget process. Journal of Public Budgeting, Accounting \& Financial Management, $\quad$ 14(2), 273-294.

Epstein, P., Solomon, R., \& Grifel, S. (2000). High value performance measurement: For sustainable results that matter to citizens. Bottom Line, 18, 5-14.

Fleming, C., \& Barnhouse, B. (2006). Call 311: Connecting citizens to local government case study series, San Antonio customer service/311 (Report: Leaders at the core of better communities). Washington, DC: International City/County Management Association. Retrieved March 10, 2021, from https://icma.org/sites/default/files/2157_.pdf

Foley, D. (1998). We want your input: Dilemmas of citizen participation. Sage Public Administration Abstracts, 25(4), 140-156.

Franklin, A. L., \& Carberry-George, B. (1999). Analyzing how local governments estab lish service priorities. Public Budgeting \& Finance, 19(3), 31-46.

Giese, J. L., \& Cote, J. A. (2000). Defining consumer satisfaction. Academy of Marketing Science Review, 1(1), 1-22.

Gray, J. E., \& Chapin, L. W. (1998). Targeted community initiative: "Putting citizens first". Sage Public Administration Abstracts, 25(4), 175-194.

Hair, J. F., Black, W. C., Babin, B. J., \& Anderson, R. E. (2019). Multivariate data analysis (8th ed.). London, UK: Cengage Learning.

Handley, D. M., \& Howell-Moroney, M. (2010). Ordering stakeholder relationships and citizen participation: Evidence from the community development block grant program. Public Administration Review, 70(4), 601-609.

Hassett, W. L., \& Watson, D. J. (2003). Citizen surveys: A component of the budgetary process. Journal of Public Budgeting, Accounting and Financial Management, 15(4), 525-541.

Ho, A., \& Coates, P. (2004). Citizen-initiated performance assessment: The initial Iowa experience. Public Performance \& Management Review, 27(3), 29-50.

Hu, L. T., \& Bentler, P. M. (1999). Cut-off criteria for fit indexes in covariance structure analysis: Conventional criteria versus new alternatives. Structural Equation Modeling: A Multidisciplinary Journal, 6(1), 1-55.

Iglitzin, L. B. (1995). The seattle commons: A case study in the politics and planning of an urban village. Policy Studies Journal, 23(4), 620-635.

Irvin, R. A., \& Stansbury, J. (2004). Citizen participation in decision making: Is it worth the effort? Public Administration Review, 64(1), 55-65.

Kelly, J. M. (2003). Citizen satisfaction and administrative performance measures: Is there really a link? Urban Affairs Review, 38(6), 855-866. 
Kelly, J. M., \& Swindell, D. (2002). A multiple-indicator approach to municipal service evaluation: Correlating performance measurement and citizen satisfaction across jurisdictions. Public Administration Review, 62(5), 610-621.

King, C. S., Feltey, K. M., \& Susel, B. (1998). The question of participation: Toward authentic public participation in public administration. Public Administration Review, 58(4), 317-326.

Langton, S. (1978). Citizen participation in America: Essays on the state of the art. Lexington, MA: Lexington Books.

Mahjabeen, Z., Shrestha, K. K., \& Dee, J. A. (2009). Rethinking community participation in urban planning: The role of disadvantaged groups in Sydney metropolitan strategy. Australasian Journal of Regional Studies, 15(1), 45-63.

McArdle, K. (2012). What makes a successful rural regeneration partnership? The views of successful partners and the importance of ethos for the community development professional. Community Development, 43(3), 333-345. doi:10.1080/15575330.2011.621211

Miller, G. (1985). Progressive reform and induced institutional preferences. Public Choice, 47(1), 163-81.

Morgan, E. (1984). Technocratc v. democratic options for educational policy. Review of Policy Research, 3(2), 263-278. doi:10.1111/j.1541-1338.1984.tb00119.x

NRD Program. (2016). Mục tiêu quốc gia xây dụng nông thôn mói giai đoạn 2016 - 2020 [National targets of new rural construction period 2016 - 2020]. Retrieved April 22, 2021, from http://nongthonmoi.gov.vn/Pages/gioi-thieu.aspx

Oliver, R. L. (1999). Whence consumer loyalty? Journal of Marketing, 63(4_suppl1), 33-44.

Oliver, J. E. (2000). City size and civic involvement in metropolitan America. American Political Science Review, 94(2), 361-373.

Painter, M. (2003). Public administration reform in Vietnam: Problems and prospects. Public Administration and Development, 23(3), 259-271.

Plein, L. C., Green, K. E., \& Williams, D. G. (1998). Organic planning: A New approach to public participation in local Government. The Social Science Journal, 35(4), 509-523.

Poister, T. H., \& Streib, G. (1999). Performance measurement in municipal Government: Assessing the state of the practice. Public Administration Review, 59(4), 325-335.

Poister, T. H., \& Streib, G. (2005). Elements of strategic planning and management in municipal government: Status after two decades. Public Administration Review, 65(1), 45-56. doi:10.1111/j.1540-6210.2005.00429.x

Putnam, R. D. (1993). Making democracy work: Civil traditions in modern Italy. Princeton, NJ: Princeton University Press.

Putnam, R. D. (2000). Bowling alone: The challenge and revival of American community. New York, NY: Simon \& Schuster.

Ramseook-Munhurrun, P., Lukea-Bhiwajee, S. D., \& Naidoo, P. (2010). Service quality in the public service. International Journal of Management and Marketing Research,3(1), 37-50. 
Rivenbark, W. C. (2003). Strategic planning and the budget process: A survey of municipal government. Government Finance Review, 19(5), 22-27.

Roberts, N. (2004). Public deliberation in an age of direct citizen participation. American Review of Public Administration, 34(4), 315-353.

Ross, B. H., \& Levine, M. A. (2001). Urban politics: Power in metropolitan America. $\quad$ Itasca, IL: FE Peacock.

Shadish, W. R., Cook, T. D., \& Campbell, D. T. (2002). Experimental and quasi-experimental designs for generalized causal inference. Boston, MA: Houghton, Mifflin and Company.

Smith, A. K., \& Bolton, R. N. (2002). The effect of customers' emotional responses to service failures on their recovery effort evaluations and satisfaction judgments. Journal of The Academy of Marketing Science, 30(1), 5-23. doi:10.1177/03079450094298

Smith, G. E., \& Huntsman, C. A. (1997). Reframing the metaphor of the citizen-government relationship: A value-centered perspective. Public Administration Review, 57(4), 309-318.

Spreng, R. A., MacKenzie, S. B., \& Olshavsky, R. W. (1996). A reexamination of the determinants of consumer satisfaction. Journal of Marketing, 60(3), 15-32.

Tewari, D. D., \& Isemonger, A. G. (1998). Joint forest management in south gujarat, india: A case of successful community development. Community Development Journal, 33(1), 32-40. doi:10.1093/cdj/33.1.32

Thomas, J. C. (1995). Public participation in public decisions. San Francisco, CA: Jossey Bass.

Tran, T. B. (2018). Sụ tham gia của nguoòi dân xây dụng Phương văn minh đô thị tại Thành phố Cà Mau [Citizen participation in building a civilized urban ward in Ca Mau City] (Master's thesis). University of Economics Ho Chi Minh City, Ho Chi Minh City, Vietnam. Retrieved March 10, 2021, from https://digital.lib.ueh.edu.vn/handle/UEH/58826

Trochim, W. M. K., Donnelly, J. P., \& Arora, K. (2016). Research methods: The essential knowledge base. Boston, MA: Cengage Learning.

Tse, D. K., \& Wilton, P. C. (1988). Models of consumer satisfaction formation: An extension. Journal of Marketing Research, 25(2), 204-212.

Verba, S., \& Nie, N. H. (1987). Participation in America: Political democracy and social equality. Chicago, US: University of Chicago Press.

Verba, S., Schlozman, K. L., Brady, H., \& Nie, N. H. (1993). Citizen activity: Who participate? What do they say? American Political Science Review, 87(2), 303-318.

Vo, D. T. (2014). Đánh giá sụ tham gia của người dân trong xây dựng nông thôn mới: $\quad$ trường hợp tại hai xã Bình Dưong và Bình Hiệp, huyện Bình Sơn, tỉnh Quảng Ngãi [Assessing citizen participation in new rural development program: The case of Binh Duong and Binh Hiep communes, Binh Son District, Quang Ngai Province] (Master's thesis). University of Economics Ho Chi Minh City, Ho Chi Minh City, Vietnam. Retrieved March 10, 2021, from https://digital.lib.ueh.edu.vn/handle/UEH/43747?mode=full

Walters, L. C., Aydelotte, J., \& Miller, J. (2000). Putting more public in policy analysis. Public Administration Review, 60(4), 349-359. 
Wang, X. (2001). Assessing public participation in US cities. Public Performance \& Management Review, 24(4), 322-336.

Wi, A. (2019). Citizen participation as a key enabler for successful public education policies in climate change mitigation in Singapore. International Research in Geographical and Environmental Education, 28(1), 53-69. doi:10.1080/10382046.2018.1430789

Wisniewski, M. (2001). Using SERVQUAL to assess customer satisfaction with public sector services. Managing Service Quality, 11(6), 380-388.

Wu, W. N., \& Jung, K. (2016). A missing link between citizen participation, satisfaction, and public performance: Evidence from the city and county of San Francisco. International Journal of Public Sector Performance Management, 2(4), 392-410.

Yang, K., \& Callahan, K. (2007). Citizen involvement efforts and bureaucratic responsiveness: Participatory values, stakeholder pressures, and administrative practicality. Public Administration Review, 67(2), 249-264.

Yoo, J. H. (1987). Interventions and innovations for administrative reforms in Korea: The Saemaul Undong. Journal of East and $W$ 